\title{
Histopathological Profile of Therapeutic Doses of Mango Mistletoe Methanolic Extract (MMME) in Cardiac of Hypertensive Rats (DOCA-Salt)
}

\author{
Annisatul Hakimah ${ }^{1}$, Nour Athiroh Abdoes Sjakoer ${ }^{*}$, Nurul Jadid Mubarakati ${ }^{1}$ \\ ${ }^{1}$ Department of Biology, Faculty of Mathematics and Natural Sciences, Universitas Islam Malang, J1. MT. Haryono 193, Malang
}

Submission: January 2021; Revised: January 2021; Accepted: March 2021

\begin{abstract}
*Corresponding author: Nour Athiroh Abdoes Sjakoer; e-mail: nour.athiroh@unisma.ac.id; tel.: +62-85710605882
ABSTRACT. This study determined the effect of Mango mistletoe Methanolic Extract (MMME) on the cardiac's histopathological profile of hypertensive rats (DOCA-Salt) treated. The MMME was treated on fifty rats for 14 days, divided into five treatments: negative control, positive control, doses 50, 100, and $200 \mathrm{mg} / \mathrm{kg} \mathrm{BW}$ with five replications. One-way ANOVA analysis was used, namely JAMOVI with version 1.1.9.0, and for cell calculation, diameter using the IMAGE J application. Results showed that there were no significant differences in the histopathological profile of the cardiac in hypertensive rats (DOCA-Salt) treated with MMME for 14 days on the diameter of the heart muscle cells between the control (+) and control groups (-), treatments 1, 2, and 3. This is evidenced by the analysis of p-value> 0.05, namely 0.187 millimeters. Therefore, we concluded that MMME does not affect the diameter of heart/cardiac organ muscle cells. However, there was a significant difference in the amount of necrosis in the cardiac of hypertensive rats between control (+) and control (-) groups, treatments 1, 2, and 3. Based on the results, MMME reduces the number of necrosis in the heart/cardiac organ.
\end{abstract}

Keywords: Hypertension, Methanolic Extract, MMME, Cardiac Histopathology, DOCA-salt

\section{INTRODUCTION}

Indonesia is the second-largest biodiversity in the world after Brazil, which consists of tropical plants and marine biota. There are about 30,000 types of plants, 7,000 of them have medicinal properties. However, only 2,500 have been used as herb medicines [1]. Mango mistletoe (D. pentandra) is widely used in the traditional medical world. Mango parasite (Dendropthoe petandra) have been reported has potential activity as anti-plasmodium [2]. The mango parasites contain some active substances, including flavonoids, amino acids, carbohydrates, tannins, saponins, alkaloids [5,6]. In Malaysia, this parasite is used to stop roundworm infection in children [7]. In addition, it is also used to treat coughs, hypertension, diabetes, cancer, stomach ulcers, measles, diuretics, skin infections, and postpartum conditions [8 - 11]. It has the potential to be developed into an immunomodulator [11]. The mango seeds also reported as an anti-colon cancer agent [3], and the mango parasite extract reduces cholesterol and LDL levels and suppress hypertension [4].

Hypertension therapy is divided into two, namely non-pharmacological and pharmacological treatment. The non-faculty treatment used phytopharmacology products for alternative natural antihypertensive drugs. Quercetin, a flavonoids group, was reported to have potential bioactivity as an anticancer [12]. Quercetin was also reportedly found in mango parasites, and has antioxidant activity [13].
Quercetin stabilizes free radicals produced by carcinogenic compounds such as oxygen radicals, peroxide, and superoxide [14 - 15]. We predicted that mango mistletoe that containing quercetin improves the histopathological profiles of hypertensive rats. Therefore, we performed the histopathological profiles of the effect of

\section{METHODS}

This research was conducted after obtaining approval from the Research Ethics Commission of the Faculty of Medicine, Islamic University of Malang (Ethical Clearance) with No. 006 / LE.001 / IV / 03/2020. This study used an experimental method with a completely randomized design study (CRD). MMME was exposed to male Wistar rats (Rattus norvegicus) for 14 days and clinical biochemical examination of heart function and histopathological observations of male Wistar rats were carried out. This research was a true experimental design with completely randomized design on 50 rats, divided into treatment $1(50 \mathrm{mg} / \mathrm{Kg} \mathrm{BW})$, treatment 2 (100mg / Kg BW), treatment 3 (200mg / Kg BW), positive control, and negative control, five replications each group.

\section{Test Animal Acclimatization Process}

Fifty male rats were acclimatized for a week with a room temperature of approximately $24^{\circ} \mathrm{C}$ and $50-60 \%$ humidity. Rats were protected from industrial fumes and other pollutants and given food and drink. On the seventh day of 
acclimatization, the rats was weighed everyday until the treatment period for seven days.

\section{Preparation of Mango Mistletoe Methanolic Extract}

Each parasite leaf was heated at $400{ }^{\circ} \mathrm{C}-600$ ${ }^{\circ} \mathrm{C}$ until dry. After drying, then the leaves were crushed until they become Simplicia powder. Then, dry leaves of rice were ground by a blender machine [17]. Leaves powder were extracted using the maceration method. A hundred grams of mango parasite leaves were soaked in 1 liter of 90\% methanol and were shaken for 60 minutes until the solution was homogeneous and incubated for $24 \mathrm{~h}$. The supernatant was collected and evaporated using a rotary evaporator. The supernatant is an active ingredient in mango parasite leaves in methanol solvent $[17,18]$.

\section{Provision of Mango Mistletoe Methanolic Extract}

The MMME was given for 14 days. Each week the rats were weighed to determine their body weight and set the doses to be provided. Three doses of mango mistletoe was provided to the male rats, including $50 \mathrm{mg} / \mathrm{kg} \mathrm{BW}, 100 \mathrm{mg} / \mathrm{kg}$ $\mathrm{BW}$, and $200 \mathrm{mg} / \mathrm{kg} \mathrm{BW}$. After 28 days of maintaining and treating male Wistar rats, the wistar rats were injected by ketamin. Heart organ was carried out from all rats.

\section{Histopathological Examination}

The cardiac organs were placed in a $\mathrm{KCl}$ and $25 \mathrm{mM}$ PBS buffer, then keep in $40 \%$ neutral buffered formaldehyde at room temperature. Heart organ was prepared the histopathological and stained using hematoxylin and eosin. The cells were observed using a microscope Olympus (Tokyo, Japan) with 400x magnifications.

\section{Data Analysis}

All data for each group were statistically tested using one-way analysis of variance (ANOVA) method and followed by Duncan's test to differentiate between the control and treatment groups ( $\mathrm{p}<0.05$ ) by SPSS (Statistical Product and Service Solution) version 1.1.9.0.).

\section{RESULTS AND DISCUSSIONS}

\section{Histopathological Observation of Heart Necrosis}

All treatments P1, PII, and PIII were significantly reducing the number of heart necrosis cells $(p<0.001)$ (Figure 1). The P1 treatment showed a similar number of necrosis cells with negative control. Interestingly, the treatment of PII and PIII showed significantly decreasing heart necrosis cells than the positive control.

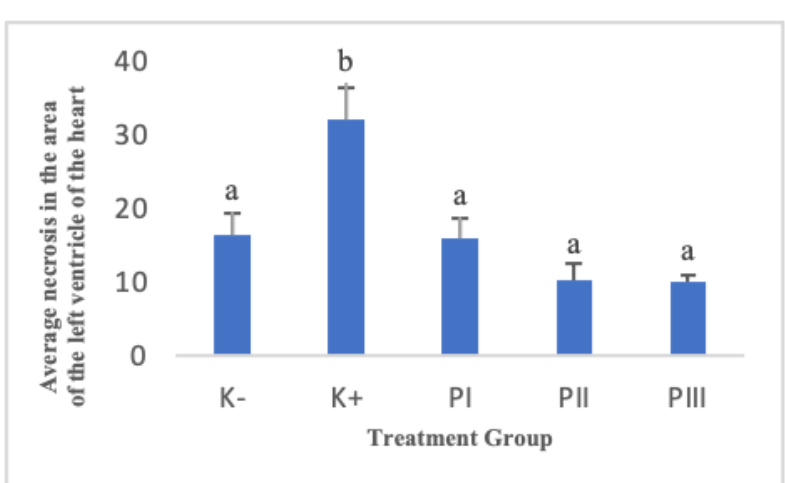

Figure 1. The Average Number of Heart Necrosis in Hypertensive Rats (DOCA-Salt) Exposed to MMME, K- for Negative Control, $\mathrm{K}+$ for Positive Control

The exposure to Mango Mistletoe Methanolic Extract (MMME) for 14 days reduced the mean number of necrosis in hypertensive rats' heart organs (DOCA-Salt). The three-dose variations have the same potential in reducing the number of necrosis of cells in the heart (left ventricle), which are indicated by (a) which indicates that there is no significant difference between the three dose variants in reducing the number of necrosis in the heart organ. However, the most optimum dose is the second dose, namely P3 (100 mg / Kg) because it can reduce the mean number of necrosis in the heart organ, especially the left ventricle, lower than the K-value.

Based on the histogram image above, it shows that there is a very, very significant difference between the $\mathrm{K}+$ group and all treatment groups. A very significant difference was indicated by the mean number of necrosis of 32.00 cells, whereas in all treatment groups the mean value of necrosis was between $16.33-10.00$ cells. Therefore, on the histogram the sign of significance is indicated by (b) which means that it has very, very significant differences between the $\mathrm{K}+$ groups with $\mathrm{K}-\mathrm{P} 1$, $\mathrm{P} 2$, and $\mathrm{P} 3$.

\section{Histopathological Anatomy of Heart Necrosis}

Cell damage (necrosis) is affected by several diseases, one of which is hypertension, which can change the structure and tissue of cells, resulting in a fatal possibility, namely cell death. Necrosis usually consists of three phases namely pycnosis, caricorrection, and cariolysis [7]. The description of the histopathology of heart cell necrosis (left ventricle) anatomy in hypertensive rats (DOCASalt) exposed to MMME for 14 days is as follows: 


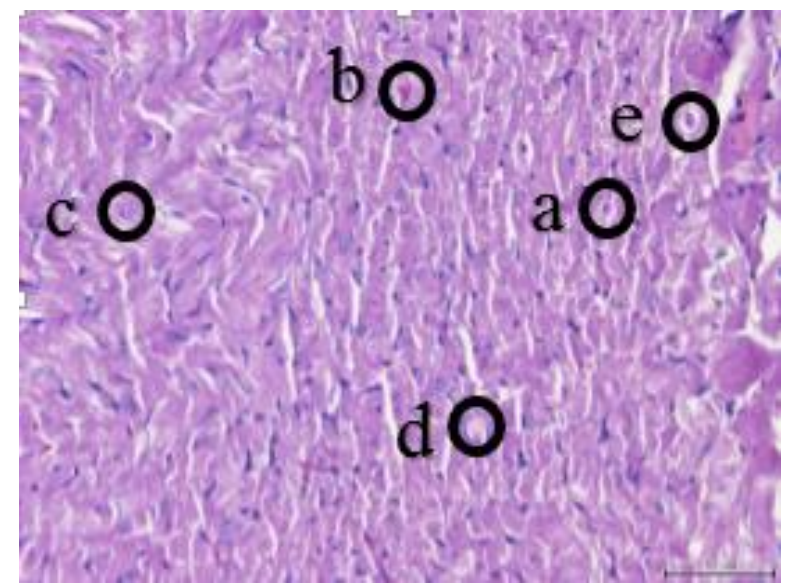

Figure 2. Histopathological Overview of the Heart (left ventricle) in Hypertensive Rats (DOCA-Salt) Exposed to MMME for 14 Days in the Positive Control Group, a. Pycnosis, b. Inflammation (inflammation due to hypertension induction), c. Kariorexist, d. Kariolysis, e. Normal cells

Table 1. The number of cardiac necrosis cells in hypertensive rats (DOCA-Salt) exposed to MMME.

\begin{tabular}{|lcccc}
\hline \multicolumn{3}{c}{ Heart Necrosis(Cell) } & Average \pm \\
\cline { 1 - 4 } Treatment & $\mathbf{1}$ & $\mathbf{2}$ & $\mathbf{3}$ & SD \\
\hline K- & 18 & 18 & 13 & $16.33 \pm 2.89^{\mathrm{a}}$ \\
\hline $\mathrm{K}+$ & 37 & 30 & 39 & $32.00 \pm 4.36^{\mathrm{b}}$ \\
\hline PI & 19 & 14 & 15 & $16.00 \pm 2.65^{\mathrm{a}}$ \\
\hline PII & 8 & 12 & 11 & $10.33 \pm 2.08^{\mathrm{a}}$ \\
\hline PIII & 11 & 9 & 10 & $10.00 \pm 1.00^{\mathrm{a}}$ \\
\hline
\end{tabular}

Based on the cardiac histopathological picture in the left ventricle of hypertensive rats (DOCASalt) exposed to MMME for 14 days, it shows that there are signs of necrosis (cell damage) due to exposure to the hypertension model using Deoxycorticosterone acetate (DOCA) at a dose 15 $\mathrm{mg} / \mathrm{KgBB}$ and $2 \% \mathrm{NaCl}$. In Figure 5.2 above is a heart histopathological picture of the positive control group, there is necrosis (cell damage) in the heart (left ventricle) in an average number that is relatively more necrosis than the normal mean number of cells. This is shown by the black circle, that necrosis consists of three types, namely pycnosis, cariorexis, and cariolysis. Fig. 2 also shows the presence of inflammation induced by exposure to DOCA-Salt as a model of hypertension. Inflammation is also caused by free radicals in the body which will also have an impact on increasing the number of cell necrosis, especially in the heart organ (left ventricle).

\section{Measurement of Heart Organ Cell Diameter (Left Ventricle)}

After measuring the diameter of heart cells (left ventricle) in hypertensive male Wistar rats (Rattus norvegicus) (DOCA-Salt) exposed to MMME, the results were tabulated based on the treatment of each group presented in the form of the histogram as follows.

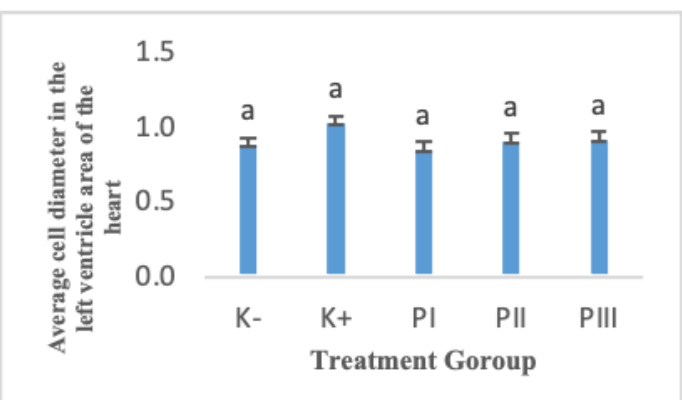

Figure 3. Histogram of Average Heart Cell Diameter Measurement (left ventricle) in Hypertensive Rats (DOCA-Salt) Exposed to MMME, Kfor Negative Control, $\mathrm{K}+$ for Positive Control, PI = Treatment 1 (50mg / KgBB), PII = Treatment $2(100 \mathrm{mg} / \mathrm{KgBB})$, PIII = Treatment 3 (200mg / KgBB)

Based on the results of the One-Way ANOVA test ( $p>0.001$ ), all treatments $\mathrm{P} 1, \mathrm{P} 2$, and $\mathrm{P} 3$ were not significantly different from the control. Figure 3 shows that there was no significant difference between the $\mathrm{K}+$ (inducer) group and all treatment groups. The insignificant difference was indicated by the mean number of cells in the $\mathrm{K}+$ group (inducer), which was $1.04 \mu \mathrm{m}$, whereas in all treatment groups the mean cell diameter was between $0.83-0.93 \mu \mathrm{m}$. Therefore, on the histogram the sign of significance is indicated by (a) which means that there is no significant difference between the $\mathrm{K}+$ groups and the $\mathrm{K}-, \mathrm{P} 1$, $\mathrm{P} 2$, and $\mathrm{P} 3$ groups. However, indirectly giving the hypertension model (DOCA-Salt) can widen the heart muscle cells' diameter although it is not significant because the response to increased blood pressure in chronic hypertension causes specific structural and functional changes [19].

The hypertensive mouse model is characterized by left heart remodeling. Characteristics include an increase in the diameter of cells in the left ventricular heart organ, the thickness of the left ventricle wall which shows an increase in echocardiogram images, while the shortening of the left ventricular fraction and decreased ejection fraction. Histological observations identified an enlarged diameter of the cardiomyocytes. The presence of left ventricular hypertrophy (LVH) and cardiac dysfunction are common complications of arterial hypertension, and as indicators of end organ damage [20].

Based on observations of cell diameter measurements in the cardiac histopathological picture in the left ventricle of hypertensive rats (DOCA-Salt) exposed to Mango Mistletoe Methanolic Extract (MMME) for 14 days, it showed that there was no significant difference in the group exposed to the hypertension model 
using Deoxycorticosterone acetate (DOCA) with a dose of $15 \mathrm{mg} / \mathrm{KgBB}$ and $\mathrm{NaCl} 2 \%$ in this case is a positive control group with all treatment groups and negative controls. In Figure 4. above is an overview of cardiac histopathology in all groups, it can be seen that the cell diameter between the control groups, both negative and positive, and all treatment groups, has no significant difference. This is as shown in the figure above, that the diameter between all groups is not a significant difference as in the results of the previous analysis. Thus, it indicates that there is hypertrophy in the heart of the left ventricle of the rats exposed to the hypertension model using Deoxycorticosterone acetate (DOCA) at a dose of $15 \mathrm{mg} / \mathrm{KgBB}$ and $\mathrm{NaCl} 2 \%$ is not too severe, and the administration of mango parasite methanolic extract is very effective in reducing hypertrophy levels in left ventricle part of the heart.

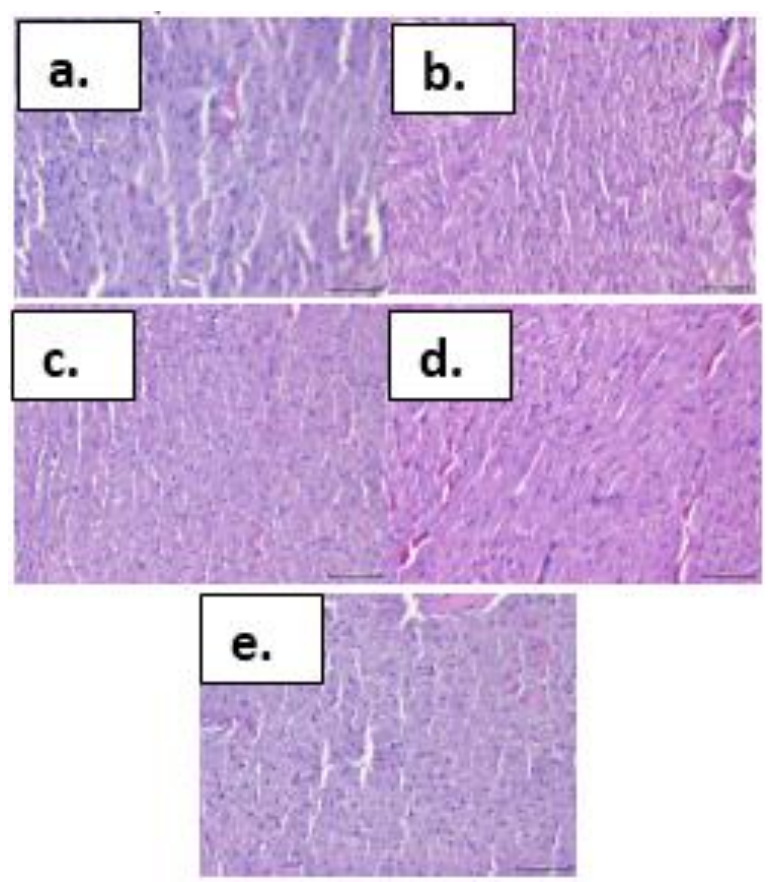

Figure 4. Histopathological Overview of Heart (left ventricle) Hypertensive Rats (DOCA-Salt) Exposed to MMME for 14 days a.) Control (-) b.) Control (+) c.) Treatment 1 d.) Treatment 2 e.) Treatment 3.

The mango parasite (Dendrophthoe pentandra L. Miq.) is one of the parasites that is easily available in Indonesia because most of the Indonesian region is lowland where mango trees are very suitable for living in the lowlands [21]. The mango parasite plant used by the community as traditional medicine or known as jamu needs to be reviewed. This is because according to the POM there are several traditional medicines that are no longer used for treatment because they have unwanted effects. In addition, natural medicines may contain toxic compound properties [22]. Benalu is one of the promising plants and still needs further exploration. Apart from being used in traditional preparations (herbal medicine), parasites also have the opportunity to be used as phyto-pharmacy [23].

In this study, the aim of this study was to determine the analysis of histopathological anatomical necrosis observation and measurement of the diameter of heart cells in hypertensive rats (DOCA-Salt) exposed to MMME for 14 days subchronic. The results of the study based on the histogram showed that the negative control group (K-) histopathological observation of heart necrosis was 16.33 , while the positive control $(\mathrm{K}$ +) was 32.00, at P1 16.00 and P2 was 10.33, and in the P3 group the mean number of necrosis was 10.00. Analysis of histopathological anatomical observation of heart cell necrosis showed an increase in the positive control group and a decrease in each treatment group when compared to controls. Based on the results of the analysis of histopathological observations of heart cell necrosis, it shows that exposure to mango parasite methanolic extract (MMME) for 14 days with a multi-level dose variant is effective in reducing the number of cell necrosis in the heart organ of hypertensive rats (DOCA-Salt). There was a significant reduction in all groups in each treatment. The results of statistical tests on the three-dose variations did not show any significant differences. The ability of MMME to affect the number of heart cell necrosis was relatively the same, and symbol found in all treatments stated that the results of the study on the histopathology of heart cell necrosis of male rats Rattus norvegicus was not significantly different from control.

One of the histopathological observations is observing cell damage (necrosis). Necrosis is cell death. Necrosis can be focal (central, middle, peripheral) or massive. Usually, necrosis is acute [24]. The characteristic of necrosis is the appearance of necrotic heart muscle fragments or cells without nuclear outlay or no cells appear to be accompanied by an inflammatory reaction. Whether or not the remaining heart cells are visible depends on the duration and type of necrosis [25]. Necrotic cell death is the death of cells that are still alive, if strong stimulation from toxic compounds can cause injury to cells or prolonged stimulation. Changes in the nucleus of cells that experience necrosis are loss of chromatin, non-vescular wrinkled nuclei, picnotics, karyolysis and carioreksis [25]. Necrotic myocytes are myocardial cells that have signs of necrosis such as picnotics (shrinkage of the cell nucleus), cariorexis (destroyed cell nuclei) and karyolysis (cell nuclei disappear) [25].

Emerging evidence supports the concept that hypertension may increase circulating proinflammatory mediators that induce oxidative 
stress. The NADPH oxidase controls the oxidative stress response which functions as an oxygen sensor to generate ROS from molecular oxygen. The upregulation of cardiac NOXs triggered by hypertension will trigger further inflammation [26]. Inflammation (inflammation) is the body's defense mechanism due to a tissue response to both local and internal destructive influences. The destructive effects (noxy) can be in the form of physical, chemical, bacterial, parasitic, acid, strong alkaline and bacteria [27].

In this case, the part of the heart that becomes the focal point of observation is the left ventricle. Research on the efficacy of herbal medicine as an antihypertensive against the heart has been carried out by [20], which stated that hypertension is an important factor in health worldwide, because it causes an increase in mortality and disability among people in many countries [28]. It is clear that hypertension is identified as a concomitant risk for cardiovascular disease. A well-known risk of cardiovascular-related death is left ventricular hypertrophy (LVH) [29].

The mechanisms that drive LVH to hypertension reveal a variety of key factors, including hemodynamic, endothelial, neurohumoral and oxidative stress. Hypertension is characterized by an increase in arterial blood pressure (BP), and subsequently affects the structural and functional changes in the left heart ventricle. Chronic stress results in hypertrophic adaptation of the existing cardiomyocytes with an increase in width, followed by thickening of the left ventricular wall [30]. Thus, LVH is a sensitive indicator of early changes in the heart due to excessive stress in hypertension [31, 32]. In addition, it is an important risk factor for coronary heart disease, heart failure and stroke in hypertensive patients [30, 33]. Indeed, recent research has shown that LVH can increase heartrelated mortality [34]. Therefore, increased cardiac performance can be achieved by inhibiting LVH independently of other risk factors [19].

It is known that hypertension is associated with ROS. The evidence provided suggests that redoxdependent pathways significantly contribute to the pathophysiology of hypertension [35] and high levels of ROS play a role in the pathophysiology

\section{CONCLUSION}

The administration of mango parasite leaf methanolic extract (MMME) to male Wistar rats Rattus novergicus on the exposure for 14 days with doses of $50 \mathrm{mg} / \mathrm{Kg}, 100 \mathrm{mg} / \mathrm{Kg}$, and 200 $\mathrm{mg} / \mathrm{Kg}$ reduced the number of heart cell necrosis and reduce the diameter of the heart cells (left ventricle) in hypertensive rats (DOCA-salt). of hypertensive cardiac remodeling [36]. The main feature of ROS-induced cellular injury is lipid peroxidation due to the effect of ROS on polyunsaturated fatty acids [37]. This results in disruption of the regulation of the lipid bilayer of the cell membrane and produces an unsaturated aldehyde, malondialdehyde (MDA) [37]. These metabolites are able to deactivate many cellular proteins by forming protein cross-links and causing cytotoxic effects [37]. Therefore, altering the bioavailability of ROS by reducing production and / or by increasing radical scavenging is a potential therapeutic modality for lowering blood pressure in hypertension and preventing left ventricular hypertrophy. Apart from enzymes that produce ROS, antioxidant defense systems are also important for dealing with oxidative stress. Hypertension intervention aims not only by increasing blood pressure, but also by reducing oxidative stress in individuals with high blood pressure which has been shown to be more effective in reducing the risk of cardiovascular disease [38].

In this case, traditional Indonesian medicine can inhibit left ventricular hypertrophy and left ventricular dysfunction through the mechanism of NADPH oxidase which can inhibit the formation of oxidative stress. Mango parasite methanolic extract (MMME) may inhibit cardiac hypertrophy through a mechanism that may involve reducing the formation of oxidative stress produced by the NADPH oxidase pathway. Treatment using MMME can efficiently lower blood pressure and reverse ventricular remodeling in hypertension. This mechanism may be related to the inhibitory effect of MMME on the formation of ROS via the cardiac NADPH oxidase pathway. This study also showed an increase in cardiac endogenous antioxidant levels with MMME administration. Therefore, these findings can provide a theoretical basis for using MMME in the treatment of hypertension and its myocardial hypertrophy. MMME may be new candidates for cardioprotective drugs for patients with hypertensive vascular disease. These findings should be important for advances in preclinical and clinical research.

\section{ACKNOWLEDGEMENT}

This study was funded by LLDIKTI 7-RISBANG Number: 187/SP2H / LT / DRPM / 2020 dated 9 March 2020. PT -LLDIKTI 7 Number: 017/SP2H/LT MULTI / LL7 / 2020 dated 17 March 2020. Researcher-LPPM Number: 199/G164 /U.LPPM/K/B.07/VIII/2020 on 7 August 2020. 


\section{REFERENCES}

[1]Directorate General of National Export Development, 2014. Traditional Herbal Medicines. Export Newsletter. Jakarta.

[2] Faiqoh. 2013. In vivo antiplasmodium activity test of parasite extract in swiss mice. Prosiding elektronik PIMNAS Program Kreativitas Mahasiswa- Penelitian.

[3] Wicaksono. 2013. Potential ethanol fraction of manga parasite (Dendrohthoe petandra) as an anti-colon cancer agent in mice (Mus musculus $\mathrm{Balb} / \mathrm{c}$ ) after induction of dextran sulvate (DSS) and azoxymethane (AOM).J Biotropika, 1(2): 75-79

[4] Rufaida F. Profile of total cholesterol levels, low density lipoprotein (LDL) and aortic histopathological picture in hypercholesterolemic rats (Rattus norvegicus) with water extract therapy of mango parasites (Dendrophthoe petandra) [diunduh 9 Maret 2015]. Tersedia dari: http://pkh.ub.ac.id/wpcontent/uploads/2012/10/0911310040FannyRufaida. pdf.

[5] Khakim, Abdul. 2000. Acute Ketoksikan Benalu Leaf Water Extract (Dendrophthoe pentandra (L.) Miq. And Dendrophthoe falcate (L.f). Ertingsh) in male mice and chemical content test. Skripsi. Yogyakarta: Fakultas Farmasi Universitas Gadjah Mada.

[6] Lamanepa ELM. 2005. Comparison of the lipid profile and development of atherosclerotic lesions in Wistar rats fed bitter melon diet with bitter melon juice diet and statins (thesis). Semarang: Magister Ilmu Biomedik Program Pascasarjana Universitas Diponegoro.

[7] Shanavaskhan, A. E. et al. 2012. Ethnomedicinal Aspects Of Angiospermic Apiphytes And Parasites Of Kerala, India. Indian Journal Of Traditional Knowledge, 11(2).

[8] Artanti, N.; Firmansyah, T. and Darmawan, A. 2012. Bioactivities Evaluation of Indonesian Mistletoe (Dendrophthoe pentandra) Leaves Extract. Journal of Applied Pharmaceutical Science, 2(1):24-27.

[9] Mustarichie, R.et al. 2015. Total Flavonoid Content and Anti-Inflammatory Properties of Indonesian Mistletoe (Dendrphthoe pentandra) Ethanol Extract. Journal of Pharmaceutical Research, 4(4), 287-302.

[10] Pramudanti DR, Padaga MC, Winarso D. Effect of water extract therapy of mango mistletoe (Dendrophthoe petandra) on albumin levels and histopathological features of the animal kidney (Rattus norvegicus) hypercholesterolemia model. [diunduh 9 Maret 2015].

[11] Ang, H. Y., el al. 2014. Immunomodulatory effects of Potentilla indicaand Dendrophthoe pentandraon Mice Spenocytes and Thymocytes. Experimental and Therapeutic Medicine, 7: 1733-1738

[12] Rosidah, S. Yulinah ,Elin, S. Gana. 1999. Anti-Inflammatory Activity Test on Wistar Rats and Phytochemical Study of Babadotan Leaf Extract and Ginger Rhizome Extract. http://bahan-alam.fa.itb.ac.id. $\quad(18$ Maret 2008).

[13] Hansen RK, Oesterreich S, Lemieux P. 1997. Quarcetin inhibits heat shock protein induction but not heat shock factor DNAbinding in human breast carcinoma cells. Biochem Biophys Res Commun; 239:85-856.

[14] Gordon, M.H. 1990. The mechanism of antioxidants action in vitro. Di dalam:B.J.F. Hudson, editor. Food Antioxidants. Elsivier Applied Science. London.

[15] Ren, W., Qiao, Z., Wang, H., Zhu, L., Zhang, L., 2003, Flavonoids: Promising Anticancer Agents, Medicinal Research Review, 23(4): 519-534

[16] BPOM. 2014. Guidelines for in vivo nonclinical toxicity testing. Jakarta: BPOM. Chem Pharm Bull., 51: 343-345.

[17] Athiroh, N., and E. Sulistyowati. 2013. Scurrula atropurpurea Increases Nitric Oxide and Decreases Malondialdehyde in Hypertensive Rats. Jurnal Universa Medicina, 32(1): 44-50.

[18] Athiroh, N., N. Permatasari, D. Sargawo dan M.A. Widodo. 2014. Antioxidative and Blood Pressure-Lowering Effects of Scurrula atropurpurea On Deoxycorticosterone Acetate-Salt Hypertensive Rats. Biomarkers and Genomic Medicine, 6(1): 32-36.

[19] Devereux RB, Bang CN, Roman MJ, Palmieri V, BomanK, Gerdts E, Nieminen MS, Papademetriou V, WachtellK, Hille DA. 2015. The products of stress-mass-heart rate left ventricular wall and cardiovascular events in hypertensive patients treated, are novel and of significance. Hypertension.; 66: 945-953.

[20] Sulistyowati E., Hsu J. H., Cheng Y.B., Chang F.R., Chen Y.F. and Yeh J.L. 2017. Indonesian herbal medicine prevents hypertension-induced left ventricular hypertrophy by diminishing NADPH oxidase-dependent oxidative stress. Oncotarget, 8(49), 86784-86798.

[21] Pramudanti DR, Padaga MC, Winarso D. 2015. Effect of water extract therapy of mango mistletoe (Dendrophthoe petandra) on albumin levels and histopathological features 
of the animal kidney (Rattus norvegicus) hypercholesterolemia model.

[22] BPOM RI. 2011Let's take natural herbal medicine and herbal medicine properly. POM info.12 (3)

[23] Artanti, N., Ma'arifa, Y,. Hanafi, M. 2006. Isolation and identification of active antioxsidant compound from star fruit mistletoe Dendrophthoe pentandra (L) Miq, Ethanol extract. Journal of applied sciences 6(8) 1659-1663.

[24] Lu and Frank C. 2010. Basic Toxicology. UI Press. Jakarta.

[25] Boya, R.D. 2011. Effect of Peg Bumi (Eurycoma longifolia Jack) Extract on the Histological Structure of Mice's Liver Cells Exposed to Paracetamol. Essay. Sebelas Maret University.

[26] Yamamoto E, Tamamaki N, Nakamura T, Kataoka K, Tokutomi Y, Dong YF, Fukuda M, Matsuba S, Ogawa H, Kim-Mitsuyama S. 2008. Excess salt causes neuronal apoptosis and inflammation in stroke-prone hypertensive rats via angiotensin II - induces NADPH oxidase activation. Stroke. 39: 3049-3056.

[27] Mandrasari, S. 2014. Administration of Mango Benalu Extract against CodeineInduced Histological Changes in Rats' Liver. Skripsi.

[28] Organisasi Kesehatan Dunia. 2009. Global health risks: death and disease burden caused by certain major risks: Organisasi Kesehatan Dunia.

[29] Cramariuc D, Gerdts E. 2016. Epidemiology of left ventricular hypertrophy in hypertension: implications for the clinic. Exp Rev Cardiovas Ther.; 14: 915-926.

[30] Gradman AH, Alfayoumi F. 2006. From left ventricular hypertrophy to congestive heart failure: management of hypertensive heart disease.Prog Cardiovasc Dis.; 48: 326-341.

[31] Dobson J, Ondhia C, Skellett AM, Coelho R. 2016. Photo gallery: phototoxic rash from celery food. Brit J Dermatol.; 175: e133.

[32] Rosei EA. 2016. JS ISH-ESH-2 Updates on the detection and follow-up of early hypertensive heart disease. J Hypertens.; 34: e192-e193.

[33] OktayAA, Lavie CJ, Milani RV, Ventura HO, Gilliland YE, Shah S, Cash ME. 2016. Perspektif saat ini pada geometri ventrikel kiri pada hipertensi sistemik. Prog Cardiovasc Dis.; 59: 235-246.

[34] Larstorp A, Okin P, Devereux R, Olsen M, Ibsen H, DahlöfB, Kjeldsen S, Wachtell K. 2011. Electrocardiographic changes in left ventricular hypertrophy and risk of major cardiovascular events in isolated systolic hypertension: studi LIFE. $J$ Hum Hypertens. 25: 178-185.

[35] Briones AM, Touyz RM. 2010. Oxidative stress and hypertension: current concepts. Curr Hypertens Rep.; 12: 135-142.

[36] Ventura-Clapier R, Garnier A, Veksler V, Joubert F. 2011. Failed heart bioenergetics. Biochim Biophy Acta.; 1813: 1360-1372.

[37] Girotti AW. 1985. Mekanisme peroksidasi lipid. J Free Rad berbagai Med.; 1: 87-95.

[38] Esterbauer H, Koller E, Lengan RG, Koster JF. 1986. There may be involvement of the lipid-peroxidation products 4hydroxyinonenal in the formation of fluorescent chromolipids. Biochem J.; 239: 405-409. 